\title{
Vitamin D: Another Protection Barrier for the Dentist in Times of SARS-CoV-2
}

\section{Diego Fernando López ${ }^{1 *}$, Valentina Rios Borrás ${ }^{2}$ and David Alejandro Rivera $^{2}$}

${ }^{1}$ Assistant Professor Orthodontics Graduate Program, School of Dentistry, Universidad del Valle, Imbanaco Medical Center researcher, Colombia

${ }^{2}$ Senior Resident, Orthodontics Graduate Program, School of Dentistry, Universidad del Valle, Colombia

*Corresponding Author: Diego Fernando López, Assistant Professor Orthodontics Graduate Program, School of Dentistry, Universidad del Valle, Imbanaco Medical Center researcher, Colombia.
Received: May 19, 2020

Published: June 24, 2020

(C) All rights are reserved by Diego Fernando López., et al.

\begin{abstract}
The knowledge about vitamin D role in human physiology is highly relevant in Dentistry, particularly considering the current world health emergency (pandemia) of the disease known as COVID-19, caused by the virus SARS-CoV-2. The deficiency of some nutrients including vitamins and hormone precursors is a factor predisposing to disease and susceptibility to infections of the respiratory tract. Additionally, in orthodontics, vitamin D is able to increase dental movement and in Implant Dentistry improves osseointegration. The aim of the present review is to provide information regarding COVID-19 and vitamin D role in the immune system and respiratory system, useful for the dental staff to help patients and themselves to take preventive actions to mitigate the consequences of COVID-19 pandemia in near future.

Keywords: Dentistry; Prevention; Vitamin D; SARS-CoV-2; COVID-19
\end{abstract}

\section{Introduction}

Vitamin D is a name encompassing various metabolic precursors and intermediate products. Ergosterol is the plant-derived precursor to Vitamin D2 (Vit D2), whereas 7-Dehydro-cholesterol is the naturally occurring precursor to Vitamin D3 (Vit D3) in the human body and it is an intermediate in cholesterol synthesis. Cholecalciferol is the dietary Vit D3. Vitamins D2 and D3 are processed to D2-calcitriol and D3 calcitriol by the same enzymatic pathways of hydroxylation. The first alcohol group $(\mathrm{OH})$ is added in $\mathrm{C}-25$ to produce 25-hydroxy-colecalcipherol, that in this article will be always referred as $25-(\mathrm{OH}) \mathrm{D}$ or calcidiol. This hydroxylation occurs in the liver. A second hydroxylation occurs in $\mathrm{C}-1$ to produce $1 \alpha, 25(\mathrm{OH}) 2-\mathrm{D}$, that will be abbreviated in this article as 1,25 DHCC or calcitriol. The second hydroxylation takes place in kidney and other tissues. The name Vitamin D (Vit D) in general applies to both D2 or D3 active forms. The active and predominant in circulating blood is $25-(\mathrm{OH}) \mathrm{D}$ and the active final hormone is 1,25-(OH)2 D. Therefore, despite its common name Vit D3, is indeed a lipophilic steroid hormone, endogenously synthesized in the skin by a reaction catalyzed by UV-B irradiation from sunlight, followed by another metabolic steps in the liver and other tissues. The amount synthesized is around 25000 international units (IU) per day. It is also supplied by exogenous dietetic sources or vitamin complements [1]. 1,25 DHCC is one of the three hormones regulating calcium/phosphate homeostasis. The other two calcium regulating hormones are calcitonin and PTH [2]. Ricketts is the consequence of severe Vit D deficiency, due to a lack of exposition to sunlight and diet deficiency. More recently, 1,25 DHCC relationship to the immune system has been studied and it is now considered as a micronutrient necessary to prevent some diseases by its role in cell proliferation and immunomodulation [3].

\section{Sources and metabolism}

The synthesis of Vit D metabolites is initiated from the provitamins ergosterol and 7-dehydrocholesterol (7-DHC). In the human skin 7-DHC reacts in two stages to form Vit D3. The first stage depends on UV-B irradiation followed by a second stage of thermic 
isomerization to form Vit D3 $[3,4]$. Then, in the liver, cholecalciferol is hydroxylated to obtain 25(OH)D3 by the cytochrome P450 hydroxylase enzymes CYP27A1 and CYP2R1. $25(\mathrm{OH}) \mathrm{D}$ is an active metabolite additionally hydroxylated in kidney and other cells expressing the enzyme CYP27B, to produce the final metabolite: $1 \alpha, 25$-DHCC (Calcitriol). This hormone interacts with a nuclear receptor (Vit D receptor, VDR) present in target organs, to induce the biological responses.
Vitamins D2 and D3 may be obtained from some diet products and vitamin supplements. Salmon, tuna, sardines and cod liver oil as well as egg yolks provide important amounts of Vit D3 while Vit D2 is synthesized in plants and fungi from UV-B action on ergosterol [5]. In the USA milk is usually fortified with $100 \mathrm{IU} / 236 \mathrm{~mL}$ of Vit D. The Vit D products from diet or supplements are absorbed predominantly in the small intestine but Vit D3 is more efficiently absorbed by chylomicrons entering the lymphatic system and drained in the upper cava vein [6] (See figure 1).

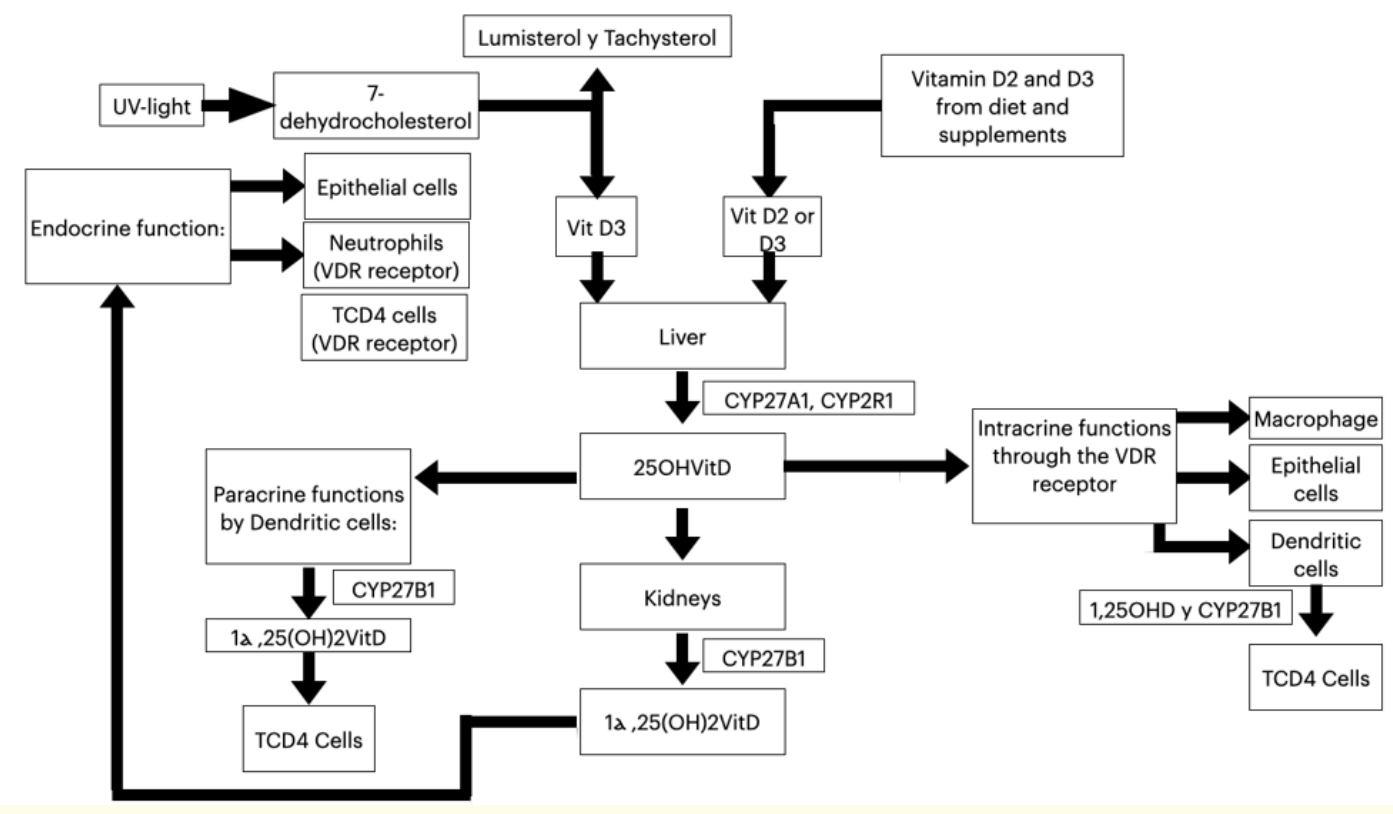

Figure 1: Interactions of Vit D metabolites with innate response cells. Modified from Lang., et al. 2017 [7].

\section{Intra and extra-skeletal functions}

The best known functions of Vit D are those related to calcium absorption in the intestine, serum calcium phosphate regulation, and bone turnover. However, the VDR gene is expressed in about 400 tissue and cell types, suggesting that Vit D functions are more than those related to bone function. Some of them are related to modulation of host defenses against antigens and pathogens, because actions depending of the transcription of VDR in the immune system regulatory pathways have been identified $[7,8]$. Some studies have demonstrated that there are multiple receptors for Vit D, linked to chromosomes, in almost all cells and tissues [9].

It has been suggested that Vit D plays an important role throughout life, for growth, development and the maintenance of a healthy body [10]. A severe deficiency of Vit D is associated to rickets and growth deficiency in children as well as osteoporosis and osteomalacia in adults. Vit D deficiency has been associated to some kinds of cancer, autoimmune diseases, cardiovascular disorders, diabetes mellitus type 1 and 2, neurocognitive disorders, infertility and adverse outcomes of pregnancy and birth $[10,11]$.

The recommended daily allowance for Vit D is $600 \mathrm{IU} /$ day and the serum levels of 25-(OH)D are considered adequate at a level of $30 \mathrm{ng} / \mathrm{mL}$ or higher. The chronic excess of Vit D is toxic, causing hypercalcemia, calcification of soft tissues and finally kidney toxicity. The symptoms of Vit D toxicity are: fatigue, nausea, vomiting, mental disability and kidney failure. 
Vitamin D and immune system

The potential role of Vit D in host immune resistance to infections has been a matter of great interest. As it is well known the immune system includes two kinds of immunity: innate and adaptive, both interacting in response to infectious diseases to recognize, prevent the propagation and expel out of the body the pathogen agents [12].

There are many studies explaining the role of Vit D in immune system response processes. The most relevant published findings are:

1. The activity of innate response cells (monocytes, macrophages, dendritic cells and natural killer cells) as well as that of $\mathrm{B}$ and $\mathrm{T}$ lymphocytes, may be regulated by Vit $\mathrm{D}$ either through the endocrine function of circulating calcitriol or paracrine actions (effects on adjacent or close cells) and/or autocrine activity (hormone action within the cell) [13].

2. Most cells of the immune system have Vit D receptors (VDRs) mainly present after stimulation [14].

3. The immune system is able to produce the enzyme 27B1 cytochrome or 25-hydroxy vitamin D3 $1 \alpha$-hydroxylase that changes the circulating form of Vit D $(25(\mathrm{OH}) \mathrm{D})$ to the active hormone $(1 \alpha, 25$ DHCC or $(1 \alpha, 25(\mathrm{OH})(2) \mathrm{D}(3))$ calcitriol) [14].

4. 1,25DHCC in the immune system induces the production of antibacterial products such as cathelicidins (broad spectrum natural antibiotic peptides), that inhibits bacterial replication [13].

5. It has been documented that endocrine, paracrine or autocrine calcitriol modulates both arms of the immune system, innate and adaptive [15].

6. It has been demonstrated that Vit D regulates inflammatory response by modification of the pro-inflammatory/anti-inflammatory balance by pathways including: (a) Regulation of cytokine levels (including IL-6, IL-8, IL-17A, IL-10 and TGF- $\beta$; (b) inhibition of the NF-KB signal pathway; (c) enhancing the expression of MAP kinase phosphatase 5; (d) inhibition of the prostaglandin pathway via reduction of PG (EP) receptors, reducing the expression of COX-2 and increasing the expression of 15-PGDH $[7,16]$.

7. Vit D deficiency apparently increases the susceptibility to respiratory tract infections, probably due to the lack of induction of cathelicidins and/or the increased production of chemokines, causing uncontrolled inflammatory response and increased risk of viral respiratory infections $[7,17]$.
8. Vit $\mathrm{D}$ modulates the innate immunologic system not only by the induction of antimicrobial peptides but inducing the differentiation of monocytes to macrophages that increases the phagocytic and chemiotaxis ability, facilitating spherocytosis (presence of sphere-shaped red cells in blood) and preventing the immunopathologic process. Vit D also modulates the adaptive immune response acting as a key mediator between innate and adaptive immunity by its influence on antigen presentation [18].

9. The renin-angiotensin system (RAS) is a central regulator of renal and cardiovascular functions. Its activation induces a cytokine storm altering this system. It has been that all the SARSCoV-2 virus effects are dependent on the activation of RAS and that Vit D acts a RAS regulator avoiding its increased expression [19].

The above effects are highly relevant for the current situation because in autopsies of COVID-19 Italian patients it was found an altered inflammatory response associated to bacterial infection and thrombosis.

\section{Vitamin D and respiratory infections}

The rate of viral replication and the concentration of pro-inflammatory cytokines are factors related to the damage of lung epithelium that affects the respiratory system [20]. From this information it has been postulated a significant association between low serum concentrations of 25-hydroxy D2 (main circulating metabolite) and the susceptibility to acute respiratory infections [15]. As a mechanism of protection, 1,25 DHCC is synthesized in lungs as a response to the lung infection, provided $25(\mathrm{OH}) \mathrm{D}$ is available (that is, in subjects with high levels of Vit D). This in turn allows the high expression of VDR in immune system cells and the respiratory tract, in order to induce broad spectrum antimicrobial response, effective against viral and bacterial respiratory pathogens [21].

The active forms of Vit D have multidirectional effects within the immune system and related to the respiratory system, including: macrophage function stimulation, activation of $\mathrm{T}$ and $\mathrm{B}$ cells, dendritic cells development; modulation of TNF expression; production of antibacterial peptides and proteins such as cathelicidins and $\beta$-defensin, reactive oxygen species and the expression of nitric oxide inducible synthase [13].

Cathelicidins and $\beta$-defensin are antimicrobial, antiviral peptides that may be secreted by epithelial cells of the respiratory tract to provide a first line of defense against invasive pathogens. This is a possible mechanism of Vit $\mathrm{D}$ action to increase innate immunity against respiratory infections [22]. 
Lang., et al. [7] found a relationship between serum concentration of 25(OH)D and 1,25 DHCC and susceptibility to different pathogens: the peak of viral infections in adults and influenza in children during winter months coincided with the reduction of epidermal synthesis of Vit D and low plasma levels of $25(\mathrm{OH}) \mathrm{D}$.

Zhou., et al. in a metanalysis published in 2019 [23] also documented the association between Vit D levels and risk of pneumonia in a community. The risk was higher when serum concentrations of Vit D were below $20 \mathrm{ng} / \mathrm{mL}$. Similar results were obtained by Martineau., et al. [21] concluding that Vit D protective effect against respiratory disease is mediated by the induction of antimicrobial peptides synthesis and the stimulation of autophagy and synthesis of reactive species of nitrogen and oxygen.

In a randomized controlled clinical trial including 25 patients of a New Zealand community, in 2018, it was evaluated the effect of a single oral dose of Vit D on patients outcome six months post-treatment. The patients with Vit D deficiency obtained better resolution of the pathology when the deficiency was treated. This finding is consistent with the known role of Vit D in the regulation of proinflammatory response [24].

A review by Zdrenghea., et al. [25] concludes that although there is no evidence that Vit D reduces viral charge, in vitro studies suggest its contribution to reduce inflammation through the reduction of pulmonary pro-inflammatory type 1 cytokines (IL-12, IFN- $\gamma$, IL-6, IL-8, IL-17 and TNF- $\alpha$ ). At the same time, there is an increment of anti-inflammatory cytokines (IL-4, IL-5, IL-10). The supplementation to obtain 25(OH)D serum levels over $30 \mathrm{ng} / \mathrm{mL}$ was associated with better respiratory outcomes but the authors remark that very high doses of Vit D are not recommended because they result in immune-suppression and may have secondary effects.

Watkins., et al. [26] postulate that Vit D supplements in patients with a deficiency are a cost effective tool to stimulate the immune system in vulnerable populations. The need of more controlled clinical trials is acknowledged and it is considered that vaccination is the main preventive action, but while there are no effective vaccines available, as is the case for SARS-CoV-2 infections, it is necessary and urgent the application of low cost alternative interventions to provide protection against multiple respiratory pathogens. A growing level of evidence suggest that Vit D supplements may be one of this kind of interventions [21].
It is a common conclusion in all these studies, the indication of supplementary doses of Vit D as an aid for immune response in the management of respiratory infections.

Susceptible populations

An important issue to implement Vit D treatments is to know the level of hypovitaminosis in the population. Demographic differences for hypovitaminosis D in the American population were studied by Ginde., et al. [27] comparing the serum levels of $25(\mathrm{OH})$ D data from 18.863 participants in the national health survey 1988 - 1994 with data from 13.369 participants in the 2001 - 2004 survey. They found that the average level was reduced from $30 \mathrm{ng} / \mathrm{mL}$ to $24 \mathrm{ng} / \mathrm{mL}$. Additionally, severe deficiency increased from $2 \%$ to $6 \%$ and levels $>30 \mathrm{ng} / \mathrm{mL}$ were reduced from $45 \%$ to $23 \%$.

To evaluate seasonal variability in serum Vit D level, Heidari., et al. in Iran [28] evaluated 576 women and 120 men in different months of the year. They found that, independently of the season, $70 \%$ of the group presented Vit D deficiency, with lower levels in women than in men. During winter and autumn months women had higher hypovitaminosis risk.

Dark skin people have higher risk of hypovitaminosis D because the melanin pigment acts as a natural sun protector reducing skin synthesis of Vit D as if it were a factor 15 UV-B protector [29]. Postmenopause women present higher prevalence of low levels of Vit D [30], particularly if osteoporosis is also present. Age is another risk factor for Vit D deficiency because aged people spend more time at home, have a dietary deficiency and the skin synthesis tends to be reduced. A 70 years old subject synthesizes four times less Vit D compared to a 20 years old subject $[31,32]$ and consequently present lower levels of calcium absorption, independently of the season [33]. School populations studied by Gordon., et al. [34,35] presented $66 \%$ of cases of Vit D deficiency ( $n=307$ adolescents), with higher prevalence during winter and if the adolescent was black.

Another susceptible group is the obese population, that has a serum level of $25(\mathrm{OH}) \mathrm{D}$ lower than normal weight persons. The serum level of 25(OH)D is inversely correlated to body weight and fatty body mass. Levels of 25(OH)D are approximately $20 \%$ lower in obese people than in normal weight people [36].

Populations with autoimmune disorders are also susceptible to Vit D deficiency. Epidemiological studies demonstrate association between Vit D deficiency and autoimmune diseases such as rheumatoid arthritis, systemic sclerosis, systemic erythematosus lupus, 
multiple sclerosis and diabetes mellitus type 1 . The supplement of Vit D to obtain an optimum level improves their innate and adaptive immune condition [37].

Considering as a main reason for Vit D deficiency the lack of daily exposure to sunlight, health workers are in risk because they spend long time in closed buildings and they frequently have night work time schedules. Haney., et al. [38] measured serum levels of 25(OH)D in 35 internal medicine residents, in Oregon, USA, during spring and autumn months, finding that they have high risk of hypovitaminosis, particularly during winter. Also, Erden., et al. [39] in Ankara Turkey, measured 25(OH)D levels in 125 anesthesiology residents and 60 hospital workers in other hospital areas. They found than only $4,8 \%$ of both groups had sufficient levels of $25(\mathrm{OH}) \mathrm{D}$ at the end of winter. Similar results obtained in a tropical country, with no winter season, were obtained by Premaor., et al. [40] in 73 residents of Porto Alegre, Brazil. The average serum level of 25(OH)D was $17.9 \pm 8.0 \mathrm{ng} / \mathrm{mL}$, considered as hypovitaminosis in this medical population. Mahdy., et al. [41] in Doha, Qatar obtained $25(\mathrm{OH}) \mathrm{D}$ levels in 340 health workers with an average value of $11.7 \mathrm{ng} / \mathrm{mL}$, lower in female subjects but in general indicative of high frequency of hypovitaminosis. Rajebi., et al. [42] in Teheran, Iran in a study of 114 nurses working in a children hospital, found that only $6.1 \%$ of this group had sufficient levels of Vit D.

The situation is similar for oral health professionals working in closed clinical environments. Drogruel., et al. [11] measured 25(OH)D in 100 dentists, auxiliary and secretaries of the Faculty of Dentistry in Kayseri, Turkey. The results indicate low levels: $12.1 \pm$ $8.37 \mathrm{ng} / \mathrm{mL}$ and 36 subjects presented simple deficiency (10 - 20 $\mathrm{ng} / \mathrm{mL}$ ), 10 presented values between $20-30 \mathrm{ng} / \mathrm{mL}$ and only 3 , including a dentist, presented normal levels (> $30 \mathrm{ng} / \mathrm{mL}$ ). Similar results are reported by Kelimeler., et al. [43] in a study of 96 members of the dental staff, showing 25(OH)D levels of $12.5 \pm 0.6 \mathrm{ng} /$ $\mathrm{mL}$.

A common recommendation from the above studies is the daily supplementation of Vit D for health workers, including dentists.

\section{SARS-CoV-2 and vitamin D}

Coronavirus are RNA virus broadly distributed among human, another mammals and birds, causing respiratory, enteric, hepatic and neurologic diseases. There are at least six coronavirus species causing human diseases. Four of them typically cause common cold symptoms in immunocompetent subjects. The other two strains (SARS-COV and MERS-COV) (SARS stands for Severe acute respiratory syndrome and MERS stands for Middle East respira- tory syndrome) are zoonotic and related to fatal conditions [44]. The SARS-CoV receptor (ACE2) is a surface protein located in endothelial cells of veins and arteries, smooth muscle cells of the arteria, small intestine epithelium and respiratory tract. ACE2 in respiratory tract is expressed in epithelial cells of alveoli, trachea and bronchia, bronchial serous glands, alveolar monocytes and macrophages [45].

SARS-CoV and MERS-CoV cause severe pneumonia in human beings and shares some structural characteristics with the new strain: SARS-CoV-2. Its genomic organization is typical of all coronavirus, with a single, positive, enveloped strain of RNA coding four viral structural proteins: Spike (S), Envelope (E), membrane (M) and 3-5 nucleocapsid proteins (N) [46]. The SARS-CoV genome has 29727 ribonucleotides and the MERS-CoV has 30119 ribonucleotides. (a positive nucleic acid strain is a nucleotide chain that is read in the 5'P-3'P direction).

Regarding SARS-CoV-2, the strain causing COVID-19, indirect evidence of the possible role of Vit $\mathrm{D}$ to reduce risk of the disease is provided by the fact that the outbreak occurred in winter, when the $25(\mathrm{OH}) \mathrm{D}$ levels are low and the number of cases in the south hemisphere, where summer was about to end, was low. Additionally, it has been shown that the severity of symptoms and rate of mortality increase with age and there is comorbidity with chronic diseases, associated with low levels of 25(OH)D [21].

It is also relevant that human DPP-4/CD26 receptor interacts with the S1 domain of a COV-19 glycoprotein, and that expression of the 4/CD26 receptor is significantly reduced in vivo when Vit D deficiency is corrected. There are also indications that the optimization of Vit D levels is able to reduce some of the immunologic critical sequelae of the infection by COVID-19, such as the prolonged response to $\gamma$-interferon and the persistent rise in the levels of IL-6, considered as a negative prognosis indicator in patients with acute pneumonia, including COVID-19 [20].

Currently, it is likely to consider a pandemic deficiency of Vit D, related to the reduced exposition to sunlight. Vit D deficiency is a condition commonly found in every racial group, in all geographic regions and all socio-economic conditions. Added to the reduced exposition to sunlight, the level of Vit D in the available nutrients is low and the increment of conditions such as obesity, hyperparathyroidism, lymphoma, malabsorption of nutrients, nephrotic syndrome, chronic hepatic insufficiency and use of anticonvulsant, antituberculosis drugs increases the likelihood of Vit D deficiency. The new conditions of nutritional habits, work conditions and daily environment also stimulate Vit D deficiency in the near future [11]. 


\section{Vitamin D levels}

The aim of Vit D supplementation is to reach and maintain the optimum serum concentrations of $25(\mathrm{OH}) \mathrm{D}$ which is considered as the best way to estimate Vit $\mathrm{D}$ requirements. However, there is controversy about the reference serum level.

The USA Medical Institute concluded that a 25(OH)D serum level of $20 \mathrm{ng} / \mathrm{mL}$ is optimum for bone health, while other experts, such as the Endocrinology Society, the International Osteoporosis Foundation and the American Geriatrics Society established a minimum level of $30 \mathrm{ng} / \mathrm{mL}$ for disease prevention [48]. In 2008, The USA Academy of Pediatrics classified a level of 25(OH)D $>20$ $\mathrm{ng} / \mathrm{mL}$ as sufficient but in 2011 this limit was increased to $30 \mathrm{ng} /$ $\mathrm{mL}$. A Global Consensus hold in 2016 defined the level of 25(OH)D $>20 \mathrm{ng} / \mathrm{mL}$ as adequate and established the following categories related to Vit D status: Sufficient, $>50 \mathrm{nmol} / \mathrm{L}(20 \mathrm{ng} / \mathrm{mL})$, insufficient, 30 - $50 \mathrm{nmol} / \mathrm{L}$ (12 - $20 \mathrm{ng} / \mathrm{mL})$, deficiency, < $30 \mathrm{nmol} / \mathrm{L}(<$ $12 \mathrm{ng} / \mathrm{mL}$ ) [44].

The Endocrine Society established as toxic levels of Vit D > 150 $\mathrm{ng} / \mathrm{mL}(375 \mathrm{nmol} / \mathrm{L})$ and considered this toxic condition as extremely infrequent [10].

The recommended daily allowance (RDA) calculated for $20 \mathrm{ng} /$ mL serum 25(OH)D was established for "healthy population" in North America [49] (men and women), taking into account the age ranges. The RDA is 600 (UI/d) for age ranges from $1-70$ and 800 UI/d for older than 71 years [45]. These values are related only to skeletal effects of Vit D. Most studies are based on optimum concentrations of 25(OH)D oscillating between 30 and $50 \mathrm{ng} / \mathrm{mL}$ (75 $125 \mathrm{nmol} / \mathrm{L}$ ), not considering extra-skeletal functions of Vit D [50].

Spedding., et al. [51] considered that the minimum ideal concentration to provide for all Vit D functions, should be higher than the concentrations indicated for specific skeletal disorders (rickets prevention (10 ng/mL; $25 \mathrm{nmol} / \mathrm{L}$ ), osteoporotic fractures (20 ng/ $\mathrm{mL} ; 50 \mathrm{nmol} / \mathrm{L}$ ) establishing the following values for more general health conditions: premature mortality: $30 \mathrm{ng} / \mathrm{mL} ; 5 \mathrm{nmol} / \mathrm{L}$; depression (30 ng/mL; $75 \mathrm{nmol} / \mathrm{L}$ ), diabetes and cardiovascular diseases (32 ng/mL; $80 \mathrm{nmol} / \mathrm{L}$ ), respiratory track infections (38 ng/ $\mathrm{mL} ; 95 \mathrm{nmol} / \mathrm{L}$ ) and cancer (40 ng/mL; $100 \mathrm{nmol} / \mathrm{L}$ ).

Previous to the administration of a supplement of Vit D, the first step is to obtain reliable data about the relationship between $25(\mathrm{OH}) \mathrm{D}$ serum concentrations and the health aspect of interest; then to measure the actual serum concentration and proceed to the administration of Vit D enough to obtain the desired concentration and measure it again to make sure the expected level is maintained, but not exceeded [52].

According to European protocols patients with a laboratory confirmed Vit D deficiency, (usually 25(OH(D $<20 \mathrm{ng} / \mathrm{mL}$ ) may be scheduled to receive a Vit D dose, body weight adjusted, as indicated in the following table [53].

\begin{tabular}{|l|c|c|}
\hline $\begin{array}{l}\text { Newborn (less } \\
\text { than one month) }\end{array}$ & $1000 \mathrm{IU} /$ day & $25 \mathrm{mg} /$ day \\
\hline One to 12 months & $2000-3000 \mathrm{IU} /$ day & $50-75 \mathrm{mg} /$ day \\
\hline $\begin{array}{l}\text { Children and } \\
\text { adolescents } \\
(1-18 \text { year) }\end{array}$ & $3000-5000 \mathrm{IU} /$ day & $75-125 \mathrm{mg} /$ day \\
\hline $\begin{array}{l}\text { Adults and elder } \\
\text { patients }\end{array}$ & $\begin{array}{c}7000-10000 \mathrm{IU} / \text { day } \\
\text { or } 50000 \mathrm{IU} / \text { week }\end{array}$ & $\begin{array}{l}175-250 \mathrm{mg} / \text { day } \\
\text { or } 1250 \mathrm{mg} / \text { week }\end{array}$ \\
\hline
\end{tabular}

Table 1

The USA Endocrine Society recommends supplements to reach a serum concentration of $25(\mathrm{OH}) \mathrm{D}>30 \mathrm{ng} / \mathrm{mL}(>75 \mathrm{nmol} / \mathrm{L})$ and to maintain a range of $40-60 \mathrm{ng} / \mathrm{mL} \mathrm{(100} \mathrm{-} 150 \mathrm{nmol} / \mathrm{L})$, as follows [54].

\begin{tabular}{|l|c|c|}
\hline$<1$ year & $400-1000 \mathrm{IU} /$ day & $10-25 \mathrm{mg}$ \\
\hline Children $>1$ year & $600-1000 \mathrm{IU} /$ day & $15-25 \mathrm{mg}$ \\
\hline Adults & $1500-2000 \mathrm{IU} /$ day & $37,5-50 \mathrm{mg}$ \\
\hline
\end{tabular}

Table 2

For obese patients $\left(\mathrm{BMI}>30 \mathrm{~kg} / \mathrm{m}^{2}\right.$ ) the recommended daily dose of Vit D is three times higher than the dose recommended for normal body weight subjects [54].

Vit D3 is preferred to Vit D2 as supplement due to its higher potency and longer half-life due to body storage 2 to 3 times higher for Vit D3 [55].

It is convenient to measure the $25(\mathrm{OH}) \mathrm{D}$ serum concentration after the treatment because there are many personal issues modifying the therapeutic effect, among them: genetics, digestive system function, effective absorption ability, weight and basal concentration.

In patients with normal absorption ability, the plasma levels of 25(OH)D may increase $0.7-1.0 \mathrm{ng} / \mathrm{mL}$ for each $100 \mathrm{IU}$ of Vit D3, but it is higher when the basal levels are low and declines when it is over $40 \mathrm{ng} / \mathrm{mL}$ [48]. 
Chang., et al. [43] indicate general treatment strategies based on the reference level of 25(OH)D and the subjacent condition to be treated:

- $\quad$ Basal level < $10 \mathrm{ng} / \mathrm{mL}: 50000 \mathrm{IU} /$ week during 6 - 8 weeks and then 800 IU/Day.

- $\quad$ Basal level 10 - 20 ng/mL: 800 - 1000 IU/day.

- Basal level 20 - 30 ng/mL: 600 - 800 IU/day.

- Malabsorption syndrome subjects: 10000 - 50000 IU/ day.

It is also recommended that the level of 25(0H)D measured three months after treatment must be monitored to implement a higher dose if necessary [43].

\section{Concluding Remarks}

Although there is no sufficient high-level scientific evidence, an additional preventive way to reduce COVID-19 incidence and its effects may be the use of supplementary Vit D, because Vit D has a protective effect against acute respiratory infections because it improves the host immune response. There is evidence of a correlation between hypovitaminosis $\mathrm{D}$ and severity of respiratory infections and about the role of Vit D in immune system regulation.

Considering the current lack of a vaccine or therapeutic treatment against COVID-19, it is recommended the implementation of a Vit D supplement for vulnerable groups, including health workers and then to extend this treatment to the whole population to mitigate the public health risks associated to COVID-19 post-infection.

The introduction of general biosecurity protocols as well as protocols for each medical or dental service, will help to prevent, control and arrest the dissemination of COVID-19 [52,53]. Meng., et al. [56] in the Stomatology Hospital at Wuhan, already had the experience that only $0.47 \%$ of the dental staff members is contaminated when the right protocols are followed.

Vit D supplements are cost effective, available and safe. Hypervitaminosis D is infrequent, but it is likely to occur if a simultaneous increment in supplemented nutrients and overdose self-administration occurs. Very high doses of Vit D should be avoided because hypervitaminosis D causes hypercalcemia and hypercalciuria. A previous measurement of Vit D serum levels is recommended in order to provide only the necessary doses. In borderline cases of deficiency, only nutritional and change of habits advice may be nec- essary. It is also worth to remind orthodontist and prosthodontists that there is evidence of the ability of Vit D to increase orthodontic dental movement and implant osseointegration [57-60]. Therefore, moderately high levels of Vit D in your patients will also be useful in your clinical practice.

\section{Recommendations}

Vit D deficiency contributes to an increased risk of respiratory infections, including COVID-19, particularly in more than 60 years old adults, menopause, pregnancy, overweight, diabetes mellitus or any other immune deficiency, smokers, and health workers, including the dental staff. For risk groups of population, it is recommended to increase the 25(OH)D serum levels to at least $40 \mathrm{ng} /$ $\mathrm{mL}$, particularly in isolation periods such as the current pandemia when sunlight exposure is additionally reduced.

\section{Bibliography}

1. McCullough PJ., et al. "Daily oral dosing of vitamin D3 using 5000 T0 50,000 international units a day in long-term hospitalized patients: Insights from a seven year experience". The Journal of Steroid Biochemistry and Molecular Biology 189 (2019): 228-239.

2. Hewison M. "An update on vitamin D and human immunity". The Journal of Clinical Endocrinology 76.3 (2012): 315-325.

3. Hossein-Nezhad A and Holick MF. "Vitamin D for health: A global perspective". Mayo Clinic Proceedings 88.7 (2013): 720755.

4. T Chen and Z Lu MFH. "Photobiology of Vitamin D". In: MF Holick (Edition.), Vitamin D”. Molecular Medicine and Clinical Applications 25.1 (2010): 175-187.

5. Feldman D. Vitamin D. In: FELDMAN DBT-VD Second E, editor. 2nd Edition [Internet]. Burlington: Academic Press; 2005. p. 1845-92. Available from: http://www.sciencedirect.com/science/article/pii/B9780122526879501091.

6. Borella E., et al. "Vitamin D: A new anti-infective agent?" Annals of the New York Academy of Sciences 1317.1 (2014): 76-83.

7. Lang PO and Aspinall R. "Vitamin D Status and the Host Resistance to Infections: What It Is Currently (Not) Understood". Clinical Therapeutics 39.5 (2017): 930-945.

8. Beard JA., et al. "Vitamin D and the anti-viral state". Journal of Clinical Virology 50.3 (2011):194-200. 
9. Pludowski P., et al. "Vitamin D effects on musculoskeletal health, immunity, autoimmunity, cardiovascular disease, cancer, fertility, pregnancy, dementia and mortality-A review of recent evidence". Autoimmunity Reviews 12.10 (2013): 976989.

10. Pludowski P., et al. "Vitamin D supplementation guidelines". The Journal of Steroid Biochemistry and Molecular Biology 175.2016 (2018): 125-135.

11. Doğruel F., et al. "Investigation of Vitamin D levels in medical staff in a dental clinic". The Nigerian Journal of Clinical Practice 22.4 (2019): 573-577.

12. Bikle DD. "Vitamin D metabolism, mechanism of action, and clinical applications". Chemical Biology 21.3 (2014): 319-329.

13. Lang PO., et al. "How important is vitamin D in preventing infections?” Osteoporosis International 24.5 (2013): 1537-1553.

14. Carlberg C., et al. "The first genome-wide view of vitamin D receptor locations and their mechanistic implications". Anticancer Research 32.1 (2012): 271-282.

15. Cannell JJ., et al. "Epidemic influenza and vitamin D". Epidemiology and Infection 134.6 (2006): 1129-1140.

16. Liu W, Zhang L, Xu H-J, Li Y, Hu C-M, Yang J-Y, et al. The AntiInflammatory Effects of Vitamin D in Tumorigenesis. Int J Mol Sci [Internet]. 2018 Sep 13;19(9):2736. Available from: https://pubmed.ncbi.nlm.nih.gov/30216977.

17. Hansdottir S and Monick MM. "Vitamin D Effects on Lung Immunity and Respiratory Diseases $1^{\text {st }}$ edition". Vitamins and Hormones 86 (2011): 217-237.

18. Greiller CL and Martineau AR. "Modulation of the immune response to respiratory viruses by vitamin D". Nutrients 7.6 (2015): 4240-4270.

19. W Zcyfesf. "SARS-CoV-2 and Covid-19: Key-Roles of the 'ReninAngiotensin' System Vitamin D Impacting Drug and Vaccine Developments (2020): 19-20.

20. McCartney DM and Byrne DG. "Optimisation of Vitamin D Status for Enhanced Immuno-protection Against Covid-19". Irish Medical Journal 113.4 (2020): 58.

21. Martineau AR., et al. "Vitamin D supplementation to prevent acute respiratory tract infections: Systematic review and meta-analysis of individual participant data". British Medical Journal (2017): 356.
22. Bals R., et al. "The peptide antibiotic LL-37/hCAP-18 is expressed in epithelia of the human lung where it has broad antimicrobial activity at the airway surface". Proceedings of the National Academy of Sciences of the United States of America 95.16 (1998): 9541-9546.

23. Zhou Y., et al. "The association between vitamin D deficiency and community-acquired pneumonia A Meta-Analysis of Observational Studies (2019): 1-7.

24. Slow S., et al. "Effect of adjunctive single high-dose vitamin D3 on outcome of community-acquired pneumonia in hospitalised adults: The VIDCAPS randomised controlled trial". Scientific Reports 8.1 (2018): 1-9.

25. Zdrenghea MT., et al. "Vitamin D modulation of innate immune responses to respiratory viral infections". Reviews in Medical Virology 27.1 (2017): 1-12.

26. Watkins RR., et al. "An update on the association of vitamin D deficiency with common infectious diseases1". Canadian Journal of Physiology and Pharmacology 93.5 (2015): 363-368.

27. Ginde AA., et al. "Demographic differences and trends of vitamin D insufficiency in the US population, 1988-2004". Archives of Internal Medicine 169.6 (2009): 626-632.

28. Heidari B and Haji Mirghassemi MB. "Seasonal variations in serum vitamin D according to age and sex". Caspian Journal of Internal Medicine 3.4 (2012): 535-540.

29. Nesby-O’Dell S., et al. "Hypovitaminosis D prevalence and determinants among African American and white women of reproductive age: third National Health and Nutrition Examination Survey, 1988-1994". The American Journal of Clinical Nutrition 76.1 (2002): 187-192.

30. Gaugris S., et al. "Vitamin D inadequacy among post-menopausal women: a systematic review". QJM: An International Journal of Medicine 98.9 (2005): 667-676.

31. Fraser L-A and Adachi JD. "Glucocorticoid-induced osteoporosis: treatment update and review". Therapeutic Advances in Musculoskeletal Disease 1.2 (2009): 71-85.

32. Holick MF., et al. "Age, vitamin D, and solar ultraviolet". Lancet 2 (1989): 1104-1105.

33. Lo CW., et al. "Vitamin D absorption in healthy subjects and in patients with intestinal malabsorption syndromes". The American Journal of Clinical Nutrition 42.4 (1985): 644-649. 
34. Sullivan SS., et al. "Adolescent girls in Maine are at risk for vitamin D insufficiency". Journal of the American Dietetic Association 105.6 (2005): 971-974.

35. Gordon CM., et al. "Prevalence of vitamin D deficiency among healthy adolescents". The Archives of Pediatrics and Adolescent Medicine 158.6 (2004): 531-537.

36. Walsh JS., et al. "Vitamin D in obesity". Current Opinion in Endocrinology, Diabetes and Obesity 24.6 (2017): 389-394.

37. Rosen Y., et al. "Vitamin D and autoimmunity". Scandinavian Journal of Rheumatology 45.6 (2016): 439-447.

38. Haney EM., et al. "Vitamin D insufficiency in internal medicine residents”. Calcified Tissue International 76.1 (2005): 11-16.

39. Erden G., et al. "Vitamin D Levels of Anesthesia Personnel, Office Workers and Outdoor Workers in Ankara, Turkey". Clinical Laboratory 62.5 (2016): 931-937.

40. Premaor MO., et al. "Hypovitaminosis D and secondary hyperparathyroidism in resident physicians of a general hospital in southern Brazil". Journal of Endocrinological Investigation 31.11 (2008): 991-995.

41. Mahdy S., et al. "Vitamin D status in health care professionals in Qatar". Saudi Medical Journal 31.1 (2010): 74-77.

42. Rajebi H., et al. "Vitamin D deficiency among female nurses of children's medical center hospital and its related factors". Acta Medica Iranica 54.2 (2016): 146-150.

43. Varkal M, Yildiz I, Saygili S, YILDIZ M, KILIÇ A, DARENDELİLER F, et al. ONE OF THE RISK GROUPS FOR VITAMIN D DEFICIENCY: HEALTH WORKERS. J Ist Faculty Med 10(2015): 41-45.

44. Zhu N., et al. "A Novel Coronavirus from Patients with Pneumonia in China, 2019". The New England Journal of Medicine 382.8 (2020): 727-733.

45. Yin Y and Wunderink RG. "MERS, SARS and other coronaviruses as causes of pneumonia”. Respirology 23.2 (2018): 130-137.

46. Song Z., et al. "From SARS to MERS, Thrusting Coronaviruses into the Spotlight". Viruses 11.1 (2019).

47. Ross AC., et al. "Dietary Reference Intakes for Calcium and Vitamin D". Washington (DC) (2011).
48. Chang S-W and Lee H-C. "Vitamin D and health - The missing vitamin in humans". Pediatrics and Neonatology 60.3 (2019): 237-244.

49. Ross AC., et al. "The 2011 report on dietary reference intakes for calcium and vitamin D from the Institute of Medicine: what clinicians need to know". The Journal of Clinical Endocrinology and Metabolism 96.1 (2011): 53-58.

50. Norman AW. "From vitamin D to hormone D: fundamentals of the vitamin D endocrine system essential for good health". The American Journal of Clinical Nutrition 88.2 (2008): 491S-499S.

51. Spedding S., et al. "Does vitamin D sufficiency equate to a single serum 25-hydroxyvitamin D level or are different levels required for non-skeletal diseases?" Nutrients 5.12 (2013): 5127-5139.

52. Heaney RP. "Guidelines for optimizing design and analysis of clinical studies of nutrient effects". Nutrition Reviews 72.1 (2014): 48-54.

53. Pludowski P., et al. "Practical guidelines for the supplementation of vitamin D and the treatment of deficits in Central Europe - recommended vitamin D intakes in the general population and groups at risk of vitamin D deficiency". Endokrynologia Polska 64 (2013): 319-327.

54. Holick MF., et al. "Evaluation, treatment, and prevention of vitamin D deficiency: an Endocrine Society clinical practice guideline". The Journal of Clinical Endocrinology and Metabolism 96.7 (2011): 1911-1930.

55. Heaney RP., et al. "Vitamin D (3) is more potent than vitamin D (2) in humans". The Journal of Clinical Endocrinology and Metabolism 96.3 (2011): E447-E452.

56. Meng L., et al. "Coronavirus Disease 2019 (COVID-19): Emerging and Future Challenges for Dental and Oral Medicine". Journal of Dental Research 99.5 (2020): 481-487.

57. Bartzela T., et al. "Medication effects on the rate of orthodontic tooth movement: A systematic literature review". American Journal of Orthodontics and Dentofacial Orthopedics 135 (2009): 16-26.

58. Tanki JZ., et al. "Influence of drugs on orthodontic tooth movement: A review". Indian Journal of Clinical Dermatology 4.1 (2013): 1-4. 
59. Collins M. "The local use of vitamin D to incrrease the rate of orthodontic tooth movement". American Journal of Orthodontics and Dentofacial Orthopedics 93 (1987): 97-104.

60. Javed F., et al. "Efficacy of Vitamin D3 supplementation on osseointegration of implants". Implant Dentistry 25.2 (2016):

281-287.

\section{Assets from publication with us}

- Prompt Acknowledgement after receiving the article

- Thorough Double blinded peer review

- Rapid Publication

- Issue of Publication Certificate

- High visibility of your Published work

Website: www.actascientific.com/

Submit Article: www.actascientific.com/submission.php

Email us: editor@actascientific.com

Contact us: +919182824667 